\title{
Use of Chlorella sp. for coating 'tommy atkins' mango fruits stored under refrigeration
}

\author{
Uso de Chlorella sp. no recobrimento de manga \\ 'tommy atkins' armazenada sob refrigeração
}

\author{
Ágda Malany Forte de Oliveira ${ }^{1 *}$; Railene Hérica Carlos Rocha ${ }^{2}$; \\ Wellinghton Alves Guedes ${ }^{3}$; George Alves Dias ${ }^{1}$; José Franciraldo de Lima ${ }^{4}$
}

\begin{abstract}
The number of studies on edible coatings that are used for extending the shelf life of fruits has steadily increased. For this purpose, it is necessary to choose raw materials with characteristics that maintain product quality. The objective of this study is to evaluate the effect of coatings of Chlorella sp. on the post-harvest conservation of 'Tommy Atkins' mango fruits. The experiment was conducted using a completely randomized design, and spray treatments (T) with $0 \%, 1 \%, 2 \%, 3 \%$, or $4 \%$ of Chlorella sp. were applied to the fruits. After the treatments, the fruits were stored for 28 days $\left(21\right.$ days at $10{ }^{\circ} \mathrm{C}$ and $42 \%$ relative humidity and 7 days at $25{ }^{\circ} \mathrm{C}$ and $42 \%$ relative humidity), and were analyzed on day 28 . There was higher pulp firmness in fruits as the concentration of Chlorella sp. was increased, and the concentration of ascorbic acid was comparatively higher (22.17\%) in fruits treated with $3 \%$ Chlorella $\mathrm{sp}$. The percentage of soluble solids and the soluble solids/titratable acidity ratio were decreased as the coating concentrations were decreased. The use of Chlorella sp. at 1\% and 2\% allowed fruit maturation without compromising fruit quality attributes during the 28-day storage period.
\end{abstract}

Key words: Cold storage. Fruit coating. Mangifera indica L.. Microalgae.

\section{Resumo}

O interesse em estudos sobre recobrimentos comestíveis têm crescido constantemente com a finalidade de estender a vida de prateleira dos frutos. Para isso é necessário à escolha de matérias-primas que possuam em sua constituição características que ajudem na manutenção da qualidade. Neste sentido, o objetivo do presente trabalho foi avaliar o efeito de recobrimentos de Chlorella sp. sob a conservação pós-colheita de manga 'Tommy Atkins'. O experimento foi instalado em delineamento inteiramente ao acaso, em que os tratamentos (T) foram constituídos por $0 \%, 1 \%, 2 \%, 3 \%$ e $4 \%$ de Chlorella sp. aplicadas nos frutos, sob aspersão. Após a aplicação dos tratamentos, as mangas permaneceram durante 21 dias a $10{ }^{\circ} \mathrm{C}$ e $42 \%$ UR e, em seguida, 7 dias a $25{ }^{\circ} \mathrm{C}$ e $42 \%$ UR, sendo analisadas aos 28 dias de armazenamento. Verificou-se maior firmeza de polpa na manga com o aumento nas concentrações do recobrimento de Chlorella sp. e maior conteúdo de ácido ascórbico $(22,17 \%)$ nos frutos tratados com 3\% de Chlorella sp. Houve redução nos sólidos solúveis e na relação SS/AT com o aumento

${ }^{1}$ Discentes, Curso de Graduação em Agronomia, Universidade Federal de Campina Grande, UFCG, Pombal, PB, Brasil. E-mail: agdamalany@hotmail.com; george.alves.dias@hotmail.com

2 Enga Agr $^{\mathrm{a}}$, Dr ${ }^{\mathrm{a}}$. em Fitotecnia, Prof ${ }^{\mathrm{a}}$ Pesquisadora, UFCG, Centro de Ciência e Tecnologia Agroalimentar, CCTA, Pombal, PB, Brasil. E-mail: raileneherica@ccta.ufcg.edu.br

${ }^{3}$ Eng $^{\circ}$ Agro $^{\circ}$, Discente, Curso de Mestrado do Programa de Pós-Graduação em Horticultura tropical, UFCG/CCTA, Pombal, PB, Brasil. E-mail: wellinghton_guedes@hotmail.com

${ }^{4}$ Pesquisador, Dr. em Engenharia de Processos, UFCG, Campina Grande, PB, Brasil. E-mail: josefranciraldo@gmail.com

* Author for correspondence 
nas concentrações do recobrimento. O uso do recobrimento de Chlorella sp. na concentração de $1 \%$ e $2 \%$, proporciona amadurecimento sem prejuízo nos atributos de qualidade dos frutos durante o armazenamento a $10{ }^{\circ} \mathrm{C}$ e 7 dias a $25^{\circ} \mathrm{C}$ e $42 \%$ UR.

Palavras-chave: Frigoconservação. Mangifera indica L.. Microalga. Revestimento do fruto.

\section{Introduction}

Brazil is the seventh largest producer and fourth largest exporter of mango in the world (FAO, 2015). In 2014, Brazil produced 1,132,449 tons of mangoes and exported 138,600 tons in the following year, representing an export record (ARAÚJO et al., 2017).

Mango fruits are rich in sugars, vitamin $\mathrm{C}$, organic acids, carotenoids, magnesium, phosphorus, iron, potassium, zinc, and calcium (DIÓGENES et al., 2015). Therefore, the nutritional potential of the fruits can be improved by developing processes that prolong shelf life and consequently preserve its nutritional and sensory characteristics (CAPARINO et al., 2012).

However, the use of new post-harvest technologies is necessary to extend fruit shelf life. At present, edible coatings, including cassava starch, chitosan, fennel extract, sunflower oil, and corn starch, are used to control the respiration rate, oxidation, and moisture transfer during post-harvest storage, and may have the same effect of modified atmosphere storage (DHALL, 2013).

Photosynthetic microorganisms such as cyanobacteria and microalgae are promising for many applications, including the direct use of biomass; aquaculture feed; food supplements; production of high-value compounds such as vitamins, pigments, and polyunsaturated fatty acids; and environmental applications such as biofuel production and wastewater treatment (FERNANDES et al., 2015).

Among the studied microalgae, Chlorella sp. is rich in proteins, fatty acids, starch, minerals, phycocyanin, chlorophyll, beta-carotene, biomass, vitamins, lipids, enzymes, and amino acids essential to humans (VIEGAS et al., 2015).
Ursu et al. (2014) have reported that the proteins of Chlorella sp. have a significantly higher emulsifying capacity than other products. In addition to the presence of compounds that are beneficial to human and animal health, Chlorella sp. has higher preservative activity than products obtained synthetically, including butylated hydroxyanisole (BHA) and butylated hydroxytoluene (BHT) (SAFI et al., 2014). Because of its rich composition and nutritional benefits, Chlorella sp. is a promising raw material for treatment of fruits as a bio-organic coating and can increase the commercial value of produce.

The objective of this study is to evaluate the effect of coatings of Chlorella sp. on the postharvest conservation of 'Tommy Atkins' mango, after storage for 28 days (21 days at $10{ }^{\circ} \mathrm{C}$ and $42 \%$ relative humidity and 7 days at $25{ }^{\circ} \mathrm{C}$ and $42 \%$ relative humidity).

\section{Materials and Methods}

The fruits were cultivated in the organic mango orchard at the Tamanduá Farm located in Santa Terezinha, near the city of Patos, Paraíba, Brazil. 'Tommy Atkins' mango fruits with green-yellowish pulp containing the peduncle were harvested manually early in the morning at maturation stage II (PROTRADE, 1992). A preliminary selection was made in the field to avoid fruits with symptoms of anthracnose, scab, scale insects, burns due to latex flow, and deformations. The fruits were packed in a single layer in containers previously coated with shredded paper to minimize the impact and friction between the fruits.

The fruits were transported to the Food Analysis Laboratory of the Federal University of Campina Grande, Pombal campus, Paraíba. In the laboratory, 
the fruits were selected by the uniformity of size and color, and those with defects or injuries due to transportation were discarded. The fruits were washed with $1 \%$ neutral detergent, rinsed, sanitized for 15 minutes with a sodium hypochlorite solution containing $100 \mathrm{ppm}$ of chlorine, and dried in the open air.

The fruits were analyzed at the time of harvest and presented the following characteristics: $\mathrm{pH}$, 3.32; titratable acidity (TA), $1.05 \%$ of citric acid; soluble solids (SS), 7.88\%; SS/TA ratio, 8.22; ascorbic acid concentration, $23.09 \%$.

The study was conducted using a completely randomized design with five repetitions per treatment and two fruits per plot. The biomass of Chlorella sp. was determined according to Lima (2016) in organic production tanks at the Tamanduá Farm. The coating concentrations were obtained by diluting solutions containing $1 \%, 2 \%, 3 \%$, and $4 \%$ of the biomass of Chlorella sp. in $1 \mathrm{~L}$ of distilled water with constant stirring until the solution was fully homogenized. The treatments were applied using a manual microspray (Flowers American Pets) with a capacity of $900 \mathrm{~mL}$. A volume of $500 \mathrm{~mL}$ of each solution was applied several times on batches of ten fruits. The fruits were turned until the external surface was thoroughly treated. After that, the fruits were dried in the open air and transferred to BOD incubators at $10^{\circ} \mathrm{C}$ and $42 \%$ relative humidity for 21 days and then for 7 days at $25{ }^{\circ} \mathrm{C}$ and $42 \%$ relative humidity in an air-conditioned room and were inspected on day 28. The analyzed variables were pulp firmness $(\mathrm{N})$, which was determined using a digital penetrometer model PTR-300 (Instrutherm) on opposite sides at the equatorial region of the fruit using 8-mm tips after removal of the peel, according to AOAC (2006). The color of the peel and pulp was analyzed by reflectometry in the color space $\mathrm{L}^{*} \mathrm{a}^{*} \mathrm{~b}$ * using a Konica Minolta colorimeter model Chromameter CR-400. Calibration was performed using a standard white plate following the manufacturer's instructions (PINHEIRO, 2009).
The homogenized pulp used in the analyses was obtained after peeling and fruit processing using a domestic centrifuge, and several variables were analyzed. TA was determined by diluting $1 \mathrm{~mL}$ of mango juice in $50 \mathrm{~mL}$ of distilled water and adding 2 drops of $1 \%$ phenolphthalein, followed by titration with sodium hydroxide at $0.1 \mathrm{M}$ under constant stirring; the results were expressed as percentage of citric acid according to IAL (2008). Ascorbic acid concentration was determined by diluting $1 \mathrm{~mL}$ of mango juice in $49 \mathrm{~mL}$ of oxalic acid, followed by titration with 2,6 dichlorophenolindophenol under constant stirring; the results were expressed as percentage of ascorbic acid according to the method of Tillman (AOAC, 2006). SS (\%) was determined in mango juice by directly reading the refraction index in a digital refractometer (Digital Refractometer) (AOAC, 2006). The SS/TA ratio was calculated by the quotient between these two variables. $\mathrm{pH}$ was determined by measuring the values in the homogenized pulp using a digital benchtop pH meter (Digimed DM-22) (IAL, 2008).

The results were subjected to analysis of variance and polynomial regression using the means obtained from the samples of each treatment and were compared using the significance of equation $\mathrm{R}^{2}$ and Student's t-test in the software SISVAR version 5.6 (FERREIRA, 2011) at a level of significance of 5\%.

\section{Results and Discussion}

The indices $\mathrm{L}^{*}, \mathrm{a}^{*}$, and $\mathrm{b}^{*}$ used for assessing the color of the peel and pulp of mangoes treated with Chlorella sp. are shown in Figure 1. There was a small variation in the peel color using the $\mathrm{L}^{*}$ index, and the mean value was 46.45 (Figure 1A). The highest $\mathrm{a}^{*}$ index value was found in uncoated fruits (Figure 1B), which presented a red hue and became fully ripe during the storage period, and these changes were observed visually by comparing the color scale of the fruits at the time of harvest (PROTRADE, 1992). However, the increase in coating concentration reduced the color and 
inhibited the development of the red hue. There was a small variation in $b^{*}$, with a tendency of decrease in the yellow hue as the coating concentrations were increased (Figure 1C). Chitarra and Chitarra (2005) observed that the changes in fruit color are due to metabolic processes related to the degradation or synthesis of pigments and are one of the main criteria for confirming fruit ripening.

Figure 1. Color $\mathrm{L}^{*}, \mathrm{a}^{*}$, and $\mathrm{b}^{*}$ of the fruit peel (A, B, and C) and pulp (D, E, F) of 'Tommy Atkins' mangoes treated with different concentrations of Chlorella sp., after storage for 28 days $\left(21\right.$ days at $10^{\circ} \mathrm{C}$ and an additional 7 days at $25^{\circ} \mathrm{C}$ at a relative humidity of $42 \%$ ), and analyzed on day 28 .
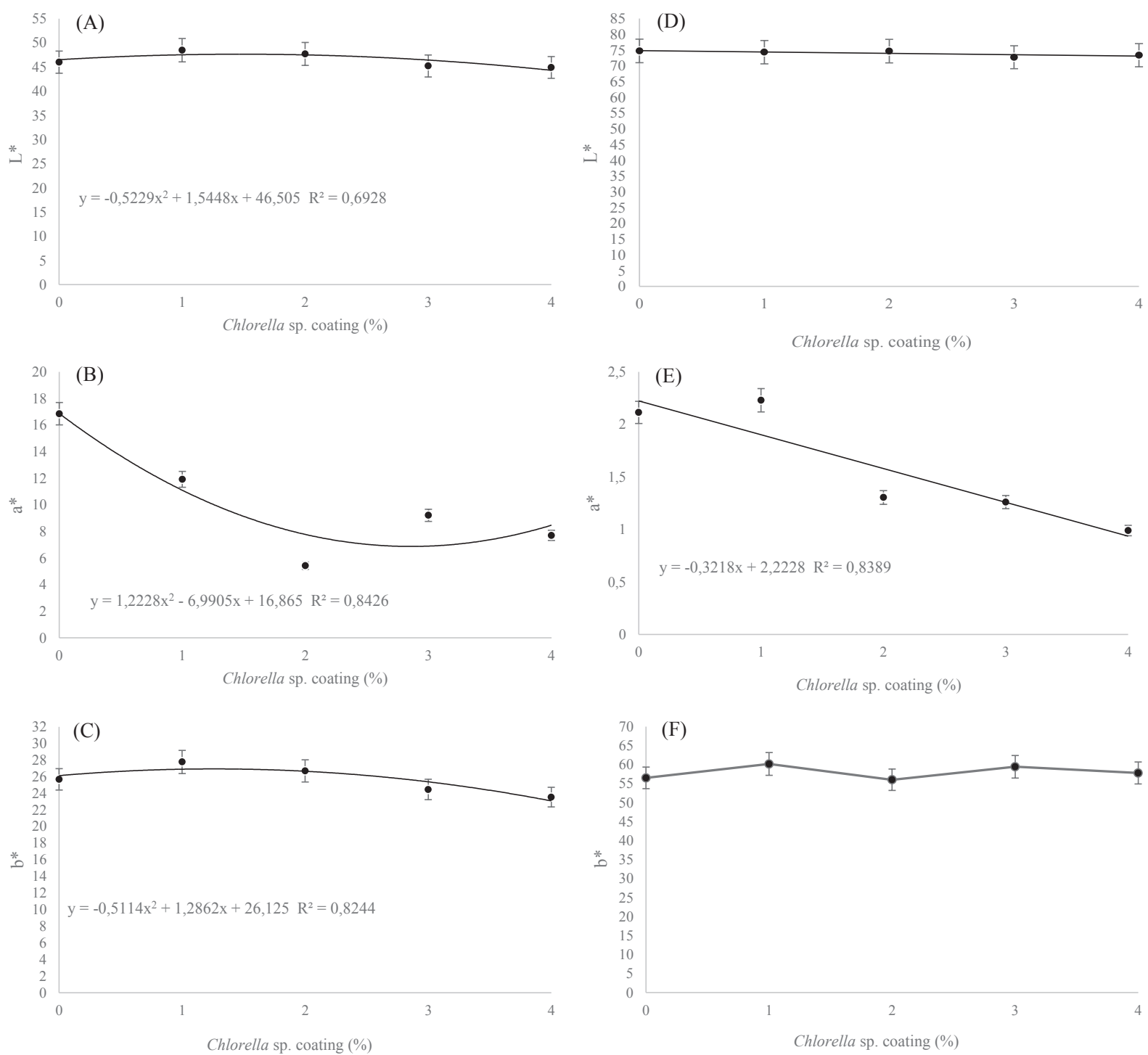

The lower rate of maturation reflected in the peel color of coated fruits compared to untreated fruits was visually evident. Therefore, there was a tendency for smaller variations in the peel color of treated fruits with coating concentrations higher

than $1 \%$, demonstrated by the values recorded for $\mathrm{a}^{*}$ at 28 days of storage (Figure 1B).

For the pulp color, there was no regression adjustment for the $\mathrm{L}^{*}$ index, and there was a small 
variation (mean of 73.9) in this characteristic as a function of the treatments (Figure 1D). The small variation in luminosity between the treatments did not affect the quality of the pulp. There was a linear decrease in $a^{*}$ as the coating concentrations were increased (Figure 1E). Moreover, there was little variation in $\mathrm{b}^{*}$ between treatments (minimum of 60 and maximum of 70, and mean of 57.98) (Figure 1F), evidenced by the completely yellow hue, which is characteristic of the mature 'Tommy Atkins' mango fruits. Although the increase in the concentrations of the Chlorella sp. caused minor changes in peel color, the concentrations used in this study did not affect the development of the yellow hue of the pulp during storage. Therefore, the use of the $1 \%$ coating of Chlorella sp. did not change the color of the peel or pulp during the 28-day storage period (21 days at $10{ }^{\circ} \mathrm{C}$ and 7 days at $25^{\circ} \mathrm{C}$ at a relative humidity of $42 \%$ ). This storage period simulated the time estimated for commercialization of the fruits in the international market.

Pulp firmness was increased as the concentration of Chlorella sp. was increased. (Figure 2A). This increase corresponded to $9.71 \mathrm{~N}$ when comparing the mean of the higher concentration in the treated group (4\%) with the untreated group ( $0 \%)$. Pulp firmness was maintained probably because Chlorella sp. treatment delayed fruit ripening and therefore prevented the softening and color change of the pulp. In this respect, Onias et al. (2016) observed a linear decrease in the firmness of 'Tommy Atkins' mango fruits treated with 3\% Spirulina platensis.

The concentration of ascorbic acid was higher (22.17\%) in fruits treated with $3 \%$ of Chlorella sp., indicating the maintenance of the concentration of ascorbic acid at $31.9 \%$ compared with untreated fruits, preventing fruit degradation (Figure 2B). This result may be an indication of the preservation of ascorbic acid during fruit storage. Souza et al. (2011) observed that the concentration of ascorbic acid tended to decrease as maturation progressed because of the direct action of the enzyme ascorbic acid oxidase (ascorbinase) in addition to oxidation and conversion of ascorbic acid to 2,3-diketogulonic acid (inactive form). Lima et al. (2012) reported that the degradation of ascorbic acid could be minimized by using organic coatings because fruits treated with starch and fennel had higher ascorbic acid concentrations than control fruits after 15 days of storage at $10{ }^{\circ} \mathrm{C}$. A similar result was found by Onias et al. (2016) in 'Tommy Atkins' mango fruits treated with 3\% Spirulina platensis, wherein the concentration of ascorbic acid in fruits did not decrease after 11 days of storage at $10{ }^{\circ} \mathrm{C}$.

There was little variation in TA as the coating concentration was increased, and the mean TA was $0.58 \%$ of citric acid (Figure 2C). A similar result was observed for $\mathrm{pH}$, which presented a minor change with the applied treatments (Figure 2D). TA is usually decreased as fruit maturation progresses, and the primary contributor to this phenomenon is organic acid consumption during respiration (ONIAS et al., 2016). Therefore, it is believed that treatment with Chlorella sp. limits the consumption of organic acids in the fruits during the conservation period. However, these characteristics were different from those found by Azerêdo et al. (2016), who observed a decrease in the acidity of 'Tommy Atkins' mangoes treated with cassava starch combined with essential oils and chitosan after 20 days of storage at $12{ }^{\circ} \mathrm{C}$ and an additional 12 days at $24^{\circ} \mathrm{C}$.

There was a small decrease in the concentration of SS as the coating concentration was increased. The highest recorded value was $15.35 \%$ in untreated fruits, and the lowest recorded value was $14.58 \%$ in fruits treated with $4 \%$ of Chlorella sp., suggesting slower maturation in fruits with increasing coating concentrations (Figure 2E), which corresponded to a decrease in SS of $5.01 \%$ when uncoated fruits were compared with fruits treated with $4 \%$ of Chlorella sp. In agreement with this result, the SS/ AT ratio was decreased linearly from 30.47 to 26.69 as the coating concentration was increased from $0 \%$ to $4 \%$ of Chlorella sp., respectively (Figure $2 \mathrm{~F}$ ), which corresponds to a reduction of $12.40 \%$ when 
uncoated fruits were compared with fruits treated with 4\% Chlorella sp. This decrease was strongly correlated with the preservation of the organic acids in fruits. A different result was observed by Lima et al. (2012), wherein the percentage of SS was not affected by the starch and fennel coatings in 'Tommy Atkins' mangoes, and SS varied from $7.81 \%$ to $10.42 \%$ in fruits stored under refrigeration, indicating the occurrence of fruit ripening.

Figure 2. Pulp firmness (A), ascorbic acid concentration (B), titratable acidity (C), pH (D), soluble solids (E), and SS/ AT ratio (F) of 'Tommy Atkins' mangoes treated with different concentrations of Chlorella sp. for 28 days (21 days at $10{ }^{\circ} \mathrm{C}$ and 7 days at $25^{\circ} \mathrm{C}$ at a relative humidity of $42 \%$ ), and analyzed on day 28 .
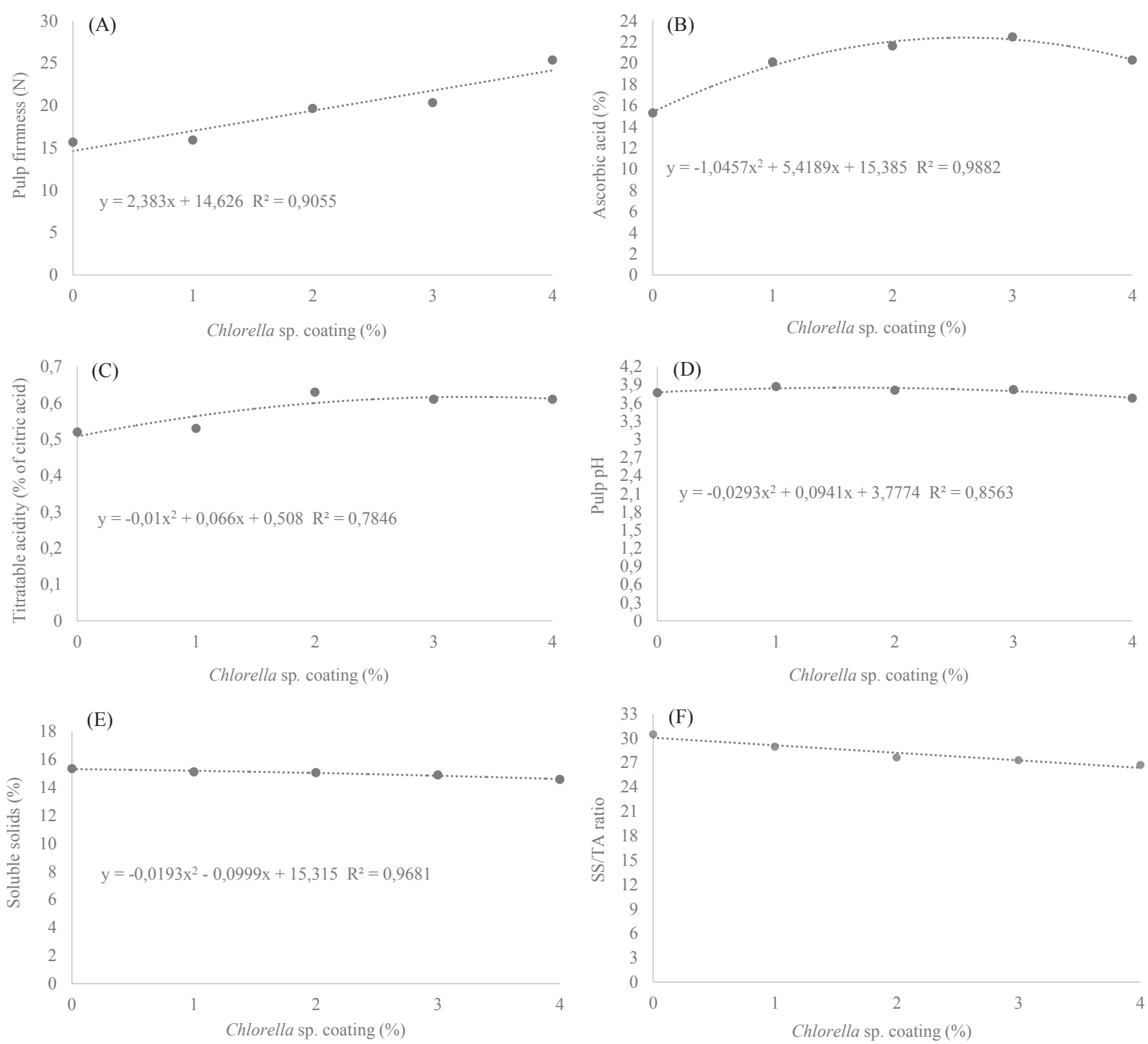


\section{Conclusions}

There was greater pulp firmness and smaller changes in the peel color of mangoes as the concentrations of Chlorella sp. were increased.

The use of coatings of Chlorella sp. at $1 \%$ and $2 \%$ promoted fruit ripening without impairing fruit quality at 28 days of storage ( 21 days at $10{ }^{\circ} \mathrm{C}$ and 7 days at $25{ }^{\circ} \mathrm{C}$ at a relative humidity of $42 \%$ ).

\section{References}

ARAÚJO, D. O.; MORAES, J. A. A.; CARVALHO, J. L. M. Fatores determinantes na mudança do padrão de produção e consumo da manga no mercado nacional. Revista em Agronegócio e Meio Ambiente, Maringá, v. 10, p. 51-73, 2017. Edição Especial.

ASSOCIATION OF OFFICIAL ANALYTICAL CHEMISTS - AOAC. Official methods of analysis of the association of official analytical chemists. $18^{\text {th }}$ ed. Gaithersburg: Editora MD, 2006.

AZERÊDO, L. P. M.; SILVA, S. D. M.; LIMA, M. A. C.; DANTAS, R. L.; PEREIRA, W. E. Quality of Tommy Atkins mango from integrated production coated with cassava starch associated with essential oils and Chitosan. Revista Brasileira de Fruticultura, Cruz das Almas, v. 38, n. 1, p. 141-150, 2016.

CAPARINO, O. A.; TANG, J.; NINDO, C. I.; SABLANI, S. S.; POWERS, J. R.; FELLMAN, J. K. Effect of drying methods on the physical properties and microstructures of mango (Philippine 'Carabao' var.) powder. Journal of Food Engineering, v. 11, p. 135-148, 2012.

CHITARRA, M. I. F.; CHITARRA, A. B. Pós-colheita de frutas e hortaliças: fisiologia e manuseio. 2. ed. Lavras: UFLA, 2005. $785 \mathrm{p}$.

DHALL, R. K. Advances in edible coatings for fresh fruits and vegetables: a review. Critical Reviews in Food and Science Nutrition, v. 53, n. 5, p. 435-450, 2013.

DIÓGENES, A. M. G.; FIGUEIRÊDO, R. M. F.; SOUSA, A. B. B. Análise comparativa de polpas de manga Haden integral e formulada. Revista Agropecuária Técnica, Areia, v. 36, n. 1, p. 30-34, 2015.
FERNANDES, B. D.; MOTA, A.; TEIXEIRA, J. A.; VICENTE, A. A. Contiuous cultivation of photosynthetic microorganisms: approaches, applications and future trends. Biotechnology Advance, v. 33, n. 6, p. 1228-1245, 2015.

FERREIRA, D. F. Sisvar: um sistema computacional de análise estatística. Ciência e Agrotecnologia, Lavras, v. 35, n. 6, p. 1039-1042, 2011.

FOOD AND AGRICULTURE ORGANIZATION OF THE UNITED NATIONS - FAO. Food and Agriculture Organization of the United Nations Statistics Division. FAOSTAT, 2016. Available at: <http://faostat3.fao.org/ browse/Q/*/E > . Accessed at: 20 aug. 2017.

INSTITUTO ADOLFO LUTZ - IAL. Normas analíticas do Instituto Adolfo Lutz: métodos físico-químicos para análise de alimentos. 4. ed. São Paulo: Instituto Adolfo Lutz, 2008. 1020 p.

LIMA, A. B.; SILVA, S. M.; ROCHA, A.; NASIMENTO, L. C.; RAMALHO, F. S. Conservação pós-colheita de manga Tommy Atkins orgânica sob recobrimentos bioorgânicos. Revista Brasileira de Fruticultura, Cruz das Almas, v. 34, n. 3, p. 704-710, 2012.

LIMA, J. F. Cultivo e secagem da microalga Chlorella sp. em diferentes concentrações de nutrientes. 2016. Tese (Doutorado em Engenharia de Processos) - Universidade Federal de Campina Grande, Campina Grande.

ONIAS, E. A.; ROCHA, R. H. C.; LIMA, J. F.; ONIAS, E. A.; FURTUNATO, T. C. S. Organic Tommy Atkins mango postharvest quality when treated with biofilms enriched by Spirulina platensis. Cientifica, Jaboticabal, v. 44, n. 3, p. 286-293, 2016.

PINHEIRO, J. M. da S. Tecnologia pós-colheita para a conservação de bananas da cultivar tropical. 2009. Dissertação (Mestrado em Produção Vegetal no Semiárido) - Universidade Estadual de Montes Claros, Montes Claros.

PROTRADE. Mangoes -export manual: tropical fruits and vegetables. Eschbom, GTZ, 1992. 34 p.

SAFI, C.; ZEBIB, B.; MERAH, O.; PONTALIER, P. Y.; VACA-GARCIA, C. Morphology, composition, production, processing and applications of Chlorella vulgaris: a review. Renewable and Sustainable Energy Reviews, v. 35, p. 265-278, 2014. 
SOUZA, M. L.; MORGADO, C. M. A.; MARQUES, K. M. M.; MATTIUZ, C. F. M.; MATTIUZ, B. Pós-colheita de mangas Tommy Atkins recobertas com quitosana. Revista Brasileira de Fruticultura, Cruz das Almas, p. 337-343, 2011. Especial.

URSU, A. V.; MARCATI, A.; SAYD, T.; SANTELHOUTELLIER, V.; DJELVEH, G.; MICHAUD, P. Extraction, fractionation and functional properties of proteins from the microalgae Chlorella vulgaris. Bioresource Technology, New York, v. 157, p. 134-139, 2014.
VIEGAS, C. V.; HACHEMI, I.; MAKI-ARVELA, P.; SMEDS, A.; AHO, A.; FREITAS, S. P.; GREGÔNIO, C. M. S.; CARBONETTI, G.; PEURLA, M.; PARANKO, J.; KUMAR, N.; DONATO, A. G. A.; MURZIN, D. Y. Algal products beyond lipids: Comprehensive characterization of different products in direct saponification of green alga Chlorella sp. Algal Research, v. 11, p. 156-164, 2015. 